\title{
Localisation and immunological properties of a 24-kDa surface protein of Haemophilus ducreyi
}

\author{
A. FRISK, E. L. ROGGEN* and TERESA LAGERGÅRD†
}

Department of Medical Microbiology and Immunology, University of Gothenburg, Guldhedsgatan 10, S-413 46 Gothenburg, Sweden and * Department of Infection and Immunity, Institute of Tropical Medicine, Antwerp, Belgium

\begin{abstract}
Summary. The cell wall and outer structures of Haemophilus ducreyi bacteria were investigated. The 24-kDa outer protein from two strains was purified with an SDS-PAGE preparative continuous-elution electrophoresis cell. The protein was further characterised by SDS-PAGE and immunoblotting, and the immunological properties were investigated by ELISA. Localisation on the bacterial surface was investigated by immuno-electronmicroscopy with a polyclonal antiserum raised against the purified protein. A triple-laminar cell wall typical of gram-negative bacteria, close cellular contact between bacterial cells and outer blebs were seen on thin sections. An additional high mol. wt band of $c .165 \mathrm{kDa}$ was seen when not treated by heating to $100^{\circ} \mathrm{C}$. A high density fibrilla-like material was detected on the bacterial cell and in the environment by negative staining and immuno-electronmicroscopy with antisera specific for the 24-kDa protein. The surface localisation of the 24$\mathrm{kDa}$ protein was confirmed by an ELISA technique with the specific antiserum and whole bacterial cells as antigen. The presence of antibodies to the $24-\mathrm{kD}$ a protein was demonstrated in antisera to 13 strains of $H$. ducreyi, indicating antigenic identity or within-species crossreactivity. Low titres of antibodies to this protein were also detected in 19 antisera raised against different strains of gram-negative bacteria, indicating cross-reactivity with other species. Antibody response to the $24-\mathrm{kDa}$ protein in rabbits immunised subcutaneously with live bacteria resulted in a secondary IgG response. Of 28 sera from patients with cultureverified chancroid, 26 manifested high titres of IgG antibodies to the 24-kDa protein, thus indicating the involvement of this antigen in the disease process in man.
\end{abstract}

\section{Introduction}

Haemophilus ducreyi causes chancroid (soft chancre, ulcus molle), a sexually transmitted disease with characteristic genital ulceration and, occasionally, painful swollen regional lymph nodes. ${ }^{1,2}$ Increasing transmission of human immunodeficiency virus (HIV) has been related to genital ulceration..$^{3-6}$

The pathogenesis of $H$. ducreyi infection is far from understood and information concerning essential virulence factors is scarce. ${ }^{1,7}$ A cytotoxin that causes death of cultured human epithelial cells has been reported. ${ }^{8}$ Lipopolysaccharide has been implicated as a virulence factor, because of its ability to cause dermal lesions in rabbits and mice and its involvement in complementmediated phagocytosis and serum killing of $H$. ducreyi..$^{9.10}$
The components responsible for the adherence of gram-negative pathogenic bacteria to epithelial surfaces often require fimbriae (pili) or other surfacebound adhesins to enable colonisation or infection, or both. ${ }^{11}$ However, previous reports concerning $H$. ducreyi have been inconsistent with regard to the presence of extracellular material and the existence of fimbriae. In ultrastructural studies, different results have been obtained with different staining methods, and even with the same method (both discontinuous and continuous extracellular material have been observed with ruthenium red staining). Moreover, some workers have reported the presence of antibodystabilised extracellular capsular material, ${ }^{12}$ or fimbriae, the monomer being a $24-\mathrm{kDa}$ protein, ${ }^{13}$ whereas others have found no evidence of extracellular material. ${ }^{14}$ A consistent finding has been the extensive cross-reactivity of $H$. ducreyi with other Haemophilus spp., and with related gram-negative bacteria. ${ }^{15,16}$

The aim of this study was to examine the outer surface structure of $H$.ducreyi with special reference to 
localisation, immunological properties and antibody response to the $24-\mathrm{kDa}$ protein.

\section{Materials and methods}

\section{Bacteria}

Three strains of $H$. ducreyi used principally in this study were obtained from the Culture Collection, University of Gothenburg (CCUG): CCUG 4438 (= CIP 542), 7470 (= CIP 76118) and 10045. In addition, the following 10 strains were used: ITMA (the Institute of Tropical Medicine, Antwerp, Belgium) 3207 and 3542 and CCUG 7781, 9276, 17675B, 17713, 18804, 26693, 27011 and 27014. Strains ITMA 3207, CCUG 4438 and CCUG 27011, do not produce any detectable cytotoxin. ${ }^{8}$

\section{Cultivation of bacteria}

$H$. ducreyi strains were cultivated in an oxygendepleted, $\mathrm{CO}_{2} 5 \%$ enriched humid atmosphere, for 2 days at $33^{\circ} \mathrm{C}$, on chocolate-GLV-3 plates obtained from the Department of Bacteriology, Sahlgrenska Hospital, Gothenburg, in an anaerobic jar with aerocult C (Merck, Darmstadt, Germany), as described previously. ${ }^{8}$ Cultivation of $H$. ducreyi in liquid media was in brain heart infusion (BHI) $5 \%$ supplemented with haemin histidine solution (BHIhemin; Sigma) 1\%, L-histidine (Fluka Chemie AG, Buch, Switzerland) $0.04 \%$, fetal calf serum $10 \%$, IsoVitale $\mathrm{X} 1 \%$, and vancomycin (Department of Bacteriology, Sahlgrenska Hospital, Gothenburg, Sweden) $0.03 \mathrm{mg} / \mathrm{ml}$. The cultures were incubated at $33^{\circ} \mathrm{C}$ for 2 days in an anaerobic jar, rotated gently at $75 \mathrm{rpm}$, as described previously. ${ }^{8}$

\section{Proteinase digestion of the 24-kDa protein}

Treatment of the crude protein preparation of strain CCUG 7470 with proteinase $\mathrm{K}$ (Sigma) was as follows: proteinase $\mathrm{K} 10 \mathrm{mg} / \mathrm{ml}$ dissolved in $50 \mathrm{~mm}$ Tris- $\mathrm{HCl}$, $\mathrm{pH} 7 \cdot 0$, containing $2 \mathrm{mM} \mathrm{MgCl}_{2}$, was mixed with an equal volume of the crude protein preparation, and incubated at $37^{\circ} \mathrm{C}$ for $30 \mathrm{~min}$ on a shaker. Tris- $\mathrm{HCl}$ buffer was used instead of proteinase as a control. After $30 \mathrm{~min}$, sample buffer was added and the digestion was determined by SDS-PAGE.

\section{Purification of the 24- $k$ Da protein}

A crude protein preparation was isolated from two strains of $H$. ducreyi (CCUG 7470 and 10045) by a slightly modified version of the method of Spinola and co-workers. ${ }^{13}$ Briefly, the crude protein preparation was isolated by harvesting 48-h colonies from chocolate GLV-3 agar plates. To inhibit protease activity, $200 \mu \mathrm{l}$ of $0.1 \mathrm{M}$ phenylmethyl-sulphonylfluoride (PMSF; Pentapharm AG, Basel, Switzerland) and $100 \mu \mathrm{l}$ of $0 \cdot 1 \mathrm{M}$ Pefabloc (Sigma) were added. The cells were suspended in $0.1 \mathrm{~m}$ Tris- $\mathrm{HCl}$ buffer, $\mathrm{pH} 8.0$, and mixed three times at $4^{\circ} \mathrm{C}$ with an Ultra Turrax $\mathrm{T} 25$ mixer, followed by centrifugation. The $24-\mathrm{kDa}$ protein was precipitated from the resulting supernate by dialysis with $0 \cdot 1 \mathrm{~m}$ phosphate-buffered saline (PBS), $\mathrm{pH} 5.0$, and was then centrifuged and solubilised by dialysis with $0.05 \mathrm{~m}$ Tris- $\mathrm{HCl}$ buffer at $\mathrm{pH} 10 \cdot 5$. Three cycles of precipitation, solubilisation and centrifugation gave the crude protein preparation. The 24$\mathrm{kDa}$ protein from strain CCUG 7470 was purified from the concentrated crude preparation with a continuous-elution electrophoresis cell (Model 491, Prep-cell; BioRad Laboratories, CA, USA). The separating gel $(14 \%, 9 \mathrm{~cm})$ and the stacking gel $(4 \%$, $2.5 \mathrm{~cm}$ ) were cast in a small gel tube (28 mm ID) with an Acrylamid:Bis $37 \cdot 5: 1$ stock $40 \%$ solution. The concentrated crude protein isolate was heated with or without 2-mercaptoethanol to $100^{\circ} \mathrm{C}$ and applied to the cylindrical gel. The buffer used was that used in the Laemmli system, ${ }^{17}$ but the runs were made at constant current ( $40 \mathrm{~mA}$ ). Fractions of $2 \mathrm{ml}$ were collected and analysed by SDS-PAGE, visualised by silver staining (BioRad) or by Western blotting (Immunoblot), or both, pooled, concentrated and stored at $-20^{\circ} \mathrm{C}$.

A Limulus amoebocyte lysate assay was performed to determine lipooligosaccharide (LOS) contamination. ${ }^{18}$

\section{Amino-acid sequencing of the 24- $k D$ a protein}

The purified protein from strain CCUG 7470 was subjected to SDS-PAGE, transferred electrophoretically to polyvinylidene difluoride membrane (Immobilon, Millipore, Bedford, MA, USA), and visualised with Ponceau S staining (Sigma). The Nterminal 25 amino-acid sequence of the membranebound protein was determined by Edman degradation with a pulsed liquid-phase Applied Biosystem (Foster City, CA, USA) model $476 \mathrm{~A}$ protein sequencer and chemicals recommended by the manufacturer. An IBI Pustell Sequence Analysis Program (version 1991) was used for comparison of the amino-acid sequence with those of other reported proteins.

\section{Protein assay}

The protein concentrations were measured as described by Bradford, ${ }^{19}$ with bovine serum albumin as the standard (BioRad Protein Assay).

\section{Sera}

To study the cross-reactivity of the 24-kDa protein, rabbit hyperimmune sera to sonicates from 13 different $H$. ducreyi strains were used. The antisera were produced as described previously. ${ }^{7,20}$ Each rabbit received $0.6-1.2 \mathrm{mg}$ of protein during the course of immunisation. The primary dose of $0.4 \mathrm{ml}, 200-400 \mu \mathrm{g}$ of protein mixed with Freund's complete adjuvant, was then given subcutaneously at four injection sites. Three weeks later a second dose was given combined 
with Freund's incomplete adjuvant. One to three booster injections were given at 2-week intervals. The rabbits were bled before immunisation to obtain preimmune sera.

To study the antibody response to the $24-\mathrm{kDa}$ protein, rabbits were immunised with whole bacteria from five different $H$. ducreyi strains (CCUG 4438, 7470 and 10045 and ITMA 3207 and 3542), as described previously. ${ }^{7,8}$ Briefly, the primary dose of $10^{8}$ bacteria $/ \mathrm{ml}$ was given intradermally at four sites. Three weeks later a second dose was given in the same manner and the last blood samples were collected 6 weeks later. Serum samples were collected weekly during the course of immunisation.

In addition, to determine cross-reactivity to the 24 $\mathrm{kDa}$ antigen of $H$. ducreyi, rabbit hyperimmune sera to the following gram-negative bacteria were used: $H$. influenzae types $\mathrm{a}$ and $\mathrm{b}$, and two non-capsulate strains; Yersinia enterocolitica type 3; and a pool of different strains-Bordetella pertussis, $B$. parapertussis, B. bronchiseptica, Pseudomonas aeruginosa (two strains), Escherichia coli, Neisseria gonorrhoeae, Vibrio parahaemolyticus, $V$. vulnificus, Campylobacter jejuni, Salmonella typhi, S. paratyphi B and Moraxella paraphenylpyruvica. Immunisation with bacterial sonicates or whole bacteria was performed as described previously. ${ }^{8,20,21}$

To produce antisera to the $24-\mathrm{kDa}$ protein, the antigen was prepared as follows. The $24-\mathrm{kDa}$ band from strain CCUG 7470 was cut out from an SDSPAGE gel and the protein was eluted with a Model 422 Electro-eluter (BioRad Laboratories). Primary immunisation was performed with two subcutaneous (s.c.) injections of protein ( $100 \mu \mathrm{g}$ in total) with Freund's complete adjuvant. Three weeks later, a second s.c. immunisation was administered at three sites, with the same dose of protein and Freund's incomplete adjuvant. Finally, one s.c. booster injection of the same dose was given at two sites 2 weeks later. The last bleeding was performed 1 week after the last immunisation and the serum was stored at $-20^{\circ} \mathrm{C}$.

To study human antibody levels to the $24-\mathrm{kDa}$ protein, 28 sera from patients with culture-verified chancroid were used (a pool of human sera from 15 healthy Swedish blood donors was used as a negative control).

\section{SDS-PAGE and immunoblotting}

Protein samples were analysed with a discontinuous SDS-PAGE system, by a modified version of the method of Laemmli. ${ }^{17}$ The acrylamide concentration was $13 \%$ with $2.6 \%$ cross-linker. The 2 -mercaptoethanol was omitted from the sample buffer and the samples were either heated to $100^{\circ} \mathrm{C}$ or run at room temperature (r.t.) in a mini-Protean II cell (BioRad Laboratories). Two different mol. wt standards (high and low) were obtained from BioRad. The gels were stained with Coomassie Brilliant Blue R-250 or silver with the BioRad silver stain kit.
Western blot analysis was performed as described by Towbin and colleagues. ${ }^{22}$ In addition to an acrylamide concentration of $13 \%$, a $7 \%$ gel was also used when analysing the $165-\mathrm{kD}$ a protein. Briefly, following protein transfer, excess binding sites of the nitrocellulose filter were blocked with BSA $1 \%$ in PBS. The antiserum to the 24-kDa protein was diluted 1 in 50 in PBS and the goat-anti-rabbit IgG horseradish peroxidase conjugate (BioRad) was diluted 1 in 3000 in PBS; substrate-colour-development reagent, 4-chloro1-naphthol (BioRad) was used to develop immunoblots.

\section{ELISA}

Two variants of ELISA were used. To evaluate antibodies to the 24-kDa protein in rabbit and human sera, microtitration plates (Greiner, Kebo Lab AB, Stockholm) were coated with the 24-kDa protein, diluted in PBS to a concentration of $1 \mu \mathrm{g} / \mathrm{ml}$, and incubated overnight at room temperature $\left(23^{\circ} \mathrm{C}\right)$. ELISA was performed as described previously. ${ }^{7}$ The plates were washed twice with PBS and blocked with bovine serum albumin (BSA) $0.5 \%$ in PBS $(0.5 \%$ BSA-PBS) for $1 \mathrm{~h}$ at $23^{\circ} \mathrm{C}$. The plates were then washed three times with PBS-Tween-20 0.05\%. Rabbit sera were diluted in $0.1 \%$ BSA-PBS-Tween, 1 in 100 when titrating IgG antibody to $H$. ducreyi, and 1 in 10 when measuring IgG antibody response to five $H$. ducreyi strains and to other gram-negative bacteria, and then diluted three-fold. When measuring human IgG antibody levels to $H$. ducreyi, the sera were diluted 1 in 10. The plates were incubated overnight and after washing, alkaline phosphatase-coupled anti-rabbit IgG or anti-human IgG (Jackson Immuno Research Lab, PA, USA) diluted in $0.1 \%$ BSA-PBS-Tween was added. The plates were incubated at $23^{\circ} \mathrm{C}$ for $5 \mathrm{~h}$. After washing, the plates were developed with $p$ nitrophenyl phosphate disodium (NPP) substrate (Sigma) $1 \mathrm{mg} / \mathrm{ml}$, absorbence being measured at $405 \mathrm{~nm}$ (Titertek Multiscan, Flow Lab). As negative controls, pre-immune serum or PBS buffer instead of test serum were used with all the other reagents. The results are expressed as dilutions that gave an absorbence of $0 \cdot 3$ above the background.

Another variant of ELISA was used to detect deposition of surface-bound antibodies specific to the 24-kDa protein on $H$. ducreyi (strain CCUG 7470). Microtitration plates (Falcon 3072, Becton Dickinson Labware, NJ, USA) were coated with whole bacteria that had been cultivated for $24 \mathrm{~h}$, washed once with PBS and suspended to OD 0.35 at $600 \mathrm{~nm}\left(c .10^{8}\right.$ bacteria $/ \mathrm{ml}$ ) in PBS; the plates were allowed to dry at $37^{\circ} \mathrm{C}$ for $20 \mathrm{~h}$. Wells were blocked with ovalbumin $2 \%$ in PBS for $2 \mathrm{~h}$ and then washed twice with PBS. Preimmune serum and anti-24-kDa serum were diluted 1 in 10 and then three-fold in duplicates. After washing, alkaline phosphatase-conjugated anti-rabbit IgG was added and the ELISA procedure was performed as 
A

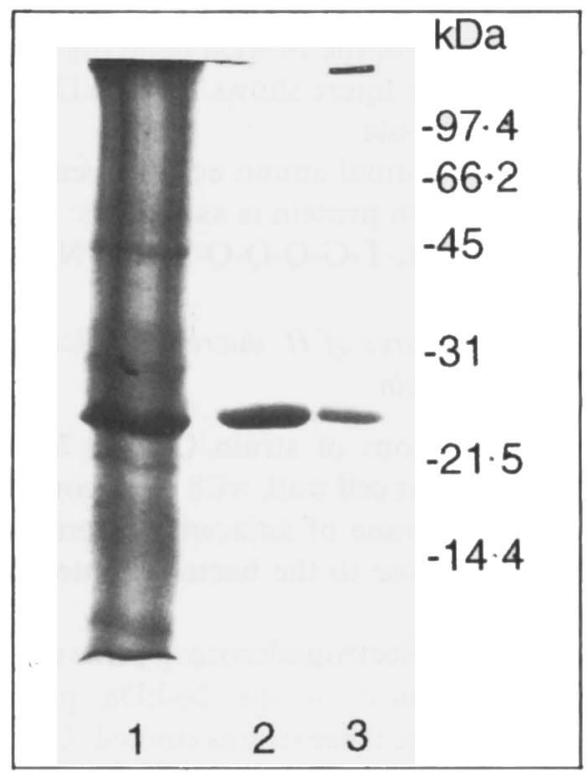

$\mathrm{C}$

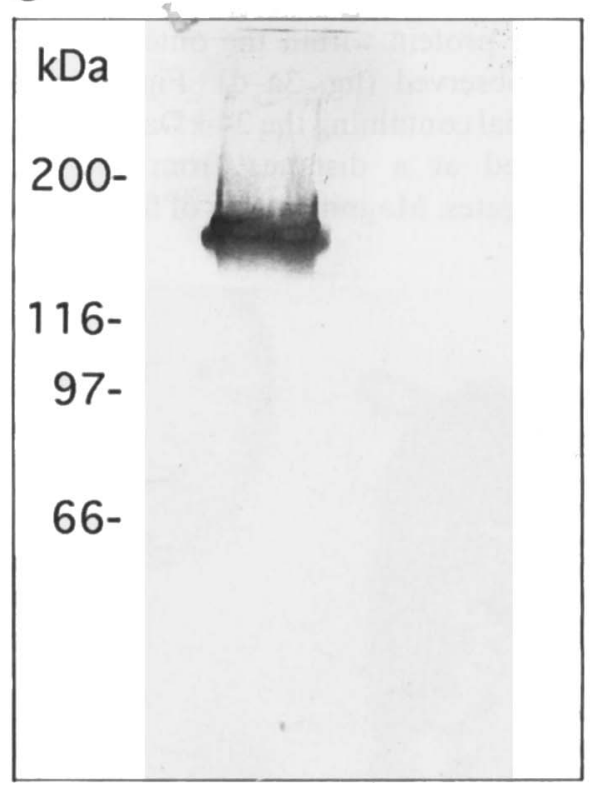

B

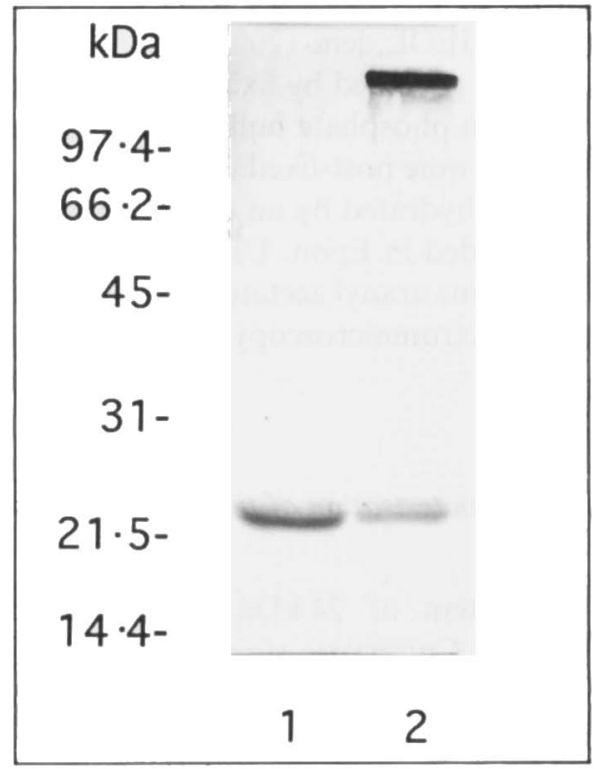

$\mathrm{D}$

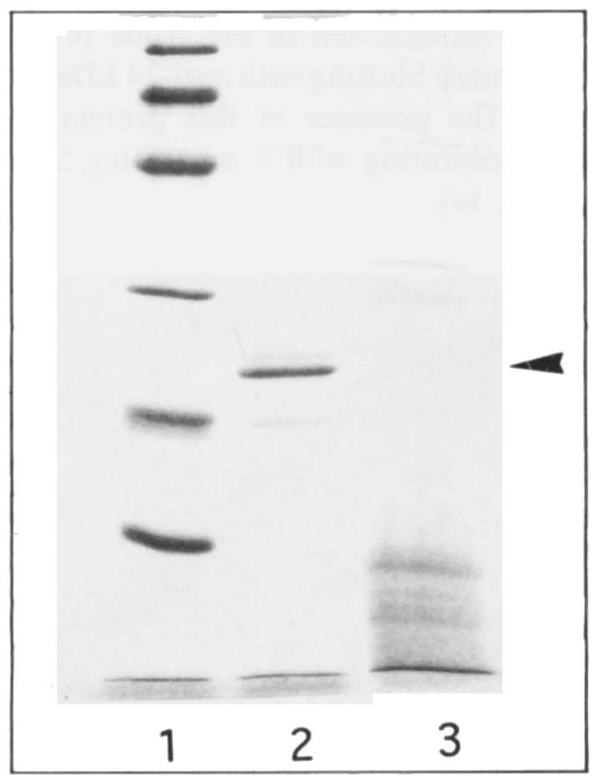

Fig. 1. a, SDS-PAGE of crude protein preparation and purified 24-kDa protein with Coomassie staining. Lane 1, crude protein preparation $\left(100^{\circ} \mathrm{C}\right) ; 2,4.5 \mu \mathrm{g}$ of purified $24-\mathrm{kDa}$ protein $\left(100^{\circ} \mathrm{C}\right) ; 3,4.5 \mu \mathrm{g}$ of purified $24-\mathrm{kDa}$ protein (not heated). b, Immunoblot of crude protein preparation with specific antiserum to the 24-kDa protein. Lane 1, crude protein preparation (heated to $100^{\circ} \mathrm{C}$ ); 2 , crude protein preparation (not heated). c, Immunoblot of crude protein preparation (not heated) with specific antiserum to the 24-kDa protein; separating gel $7 \%$. d, SDS-PAGE of crude protein preparation subjected to proteinase $\mathrm{K}$ digestion, with Coomassie staining. Lane 1, molecular mass markers $(\mathrm{kDa})$, from the top, $97 \cdot 4,66 \cdot 2,45,31,21 \cdot 5,14 \cdot 4 ; 2$, crude protein preparation (control); 3 , crude protein preparation after digestion; bands visible in lane 3 correspond to proteinase $\mathrm{K}$; arrow on the right indicates the $24-\mathrm{kDa}$ protein.

described above. As control, PBS buffer was used instead of serum. The results are expressed as dilutions that gave an absorbence of 0.3 above the background.

\section{Transmission electronmicroscopy}

Negative staining was performed with or without immunological labelling with antisera. ${ }^{23}$ Bacterial suspension $(10 \mu \mathrm{l})$ from either solid or liquid medium was applied to Formvar carbon-coated 200-mesh copper grids (Ted Pella, Ink. CA, USA) and incubated for $10 \mathrm{~min}$ and then with pre- or hyper-immune serum to the $24-\mathrm{kDa}$ protein, diluted 1 in 10,1 in 30 or 1 in 50 in $0.1 \%$ BSA-PBS-Tween, for $15 \mathrm{~min}$. After washing, the grids were treated with $10 \mathrm{~nm}$ gold-anti-rabbit IgG (Amersham International), diluted 1 in 10 in $0.1 \%$ BSA-PBS-Tween, for $15 \mathrm{~min}$. After further washing, the grids were negatively stained with ammonium 
molybdate $2 \%$-ammonium acetate $2 \%$ or ammonium molybdate $2 \%$ in distilled water, and examined by electronmicroscopy (JEOL, jem-1200 Ex, Japan).

Thin sections were prepared by fixing bacteria with glutaraldehyde $3 \%$ in phosphate buffer for $1 \mathrm{~h}$. After washing, the samples were post-fixed with $\mathrm{OsO}_{4} 1 \%$ in buffer for $90 \mathrm{~min}$, dehydrated by an ethanol gradient solution, and embedded in Epon. Ultra-thin sections were stained in aqueous uranyl acetate and lead citrate and examined by electronmicroscopy.

\section{Results}

Purification and characterisation of the 24-kDa protein

The purified protein of $24 \mathrm{kDa}$ was visualised with SDS-PAGE by Coomassie staining in a heated $\left(100^{\circ} \mathrm{C}\right)$ preparation (fig. 1a, lane 2$)$. Lane 3 of the same figure reveals a protein of $c .165 \mathrm{kDa}$ obtained without heating of the preparation. The addition or omission of 2-mercaptoethanol did not affect the behaviour of the proteins visualised with SDS-PAGE. The $165-\mathrm{kDa}$ protein could also be detected in the crude protein preparation by Western blotting with anti- $24 \mathrm{kDa}$ sera (fig. 1b, lane 2). The presence of this protein was verified by immunoblotting with a separating SDSPAGE 7\% gel (fig. 1c).

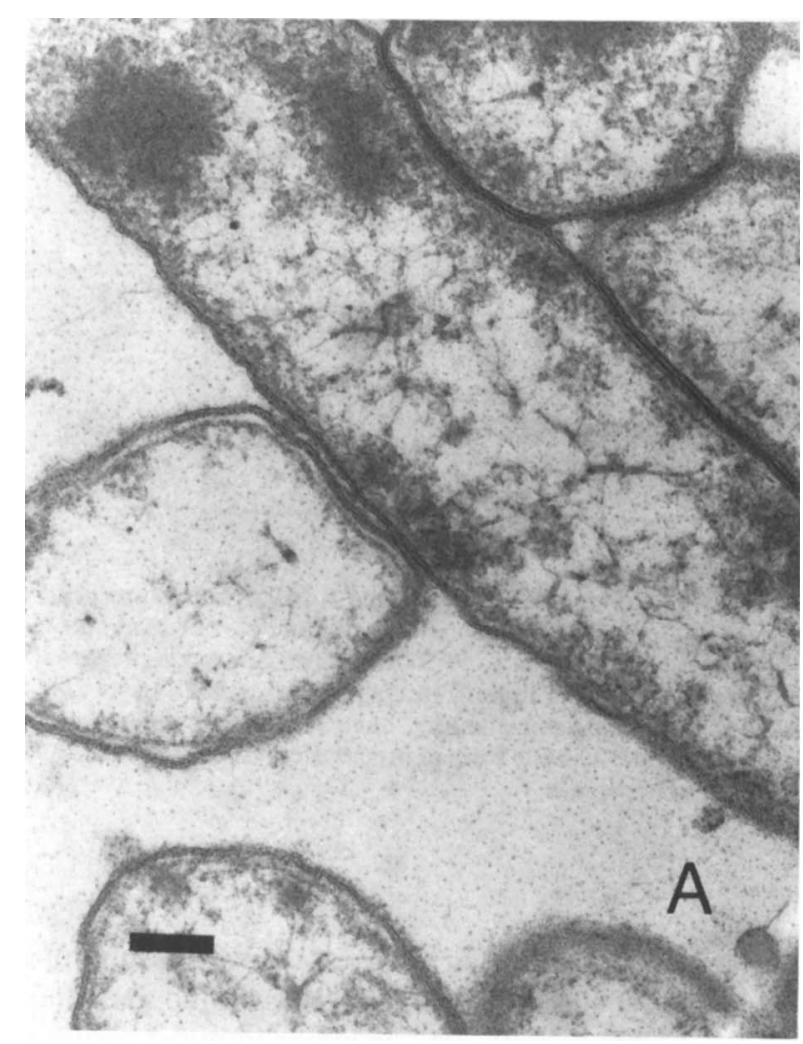

The treatment of the crude protein preparation from strain CCUG 7470 with proteinase $\mathrm{K}$, resulted in the digestion of the 24-kDa band (fig. 1d, lane 3). Lane 2 of the same figure shows the $24-\mathrm{kDa}$ protein stained with Coomassie.

The $\mathrm{N}$-terminal amino acid sequence of 25 residues of the 24-kDa protein is as follows: M-R-S-K-T-I-TF-P-V-L-K-L-T-G-Q-Q-Q-A-L-T-N-D-M-H.

\section{Outer structures of $H$. ducreyi and localisation of the 24-kDa protein}

Thin sections of strain CCUG 7470 revealed the triple-laminar cell wall, with close contact between the outer membrane of adjacent bacteria (fig. $2 \mathrm{a}$ ). Blebs were seen close to the bacterial outer membrane (fig. 2b).

Immuno-electronmicroscopy was used to determine the localisation of the $24-\mathrm{kDa}$ protein. Negative staining of the three strains studied (CCUG 4438, 7470 and 10045) revealed the presence of highly dense material surrounding the bacteria. When bacteria were stained with the gold anti-24-kDa serum, the existence of the protein within the outer filamentous material was observed (fig. 3a-d). Fig. 3a shows the outer material containing the $24-\mathrm{kDa}$ protein, disrupted and situated at a distance from the bacteria as free aggregates. Magnifications of filamentous material are

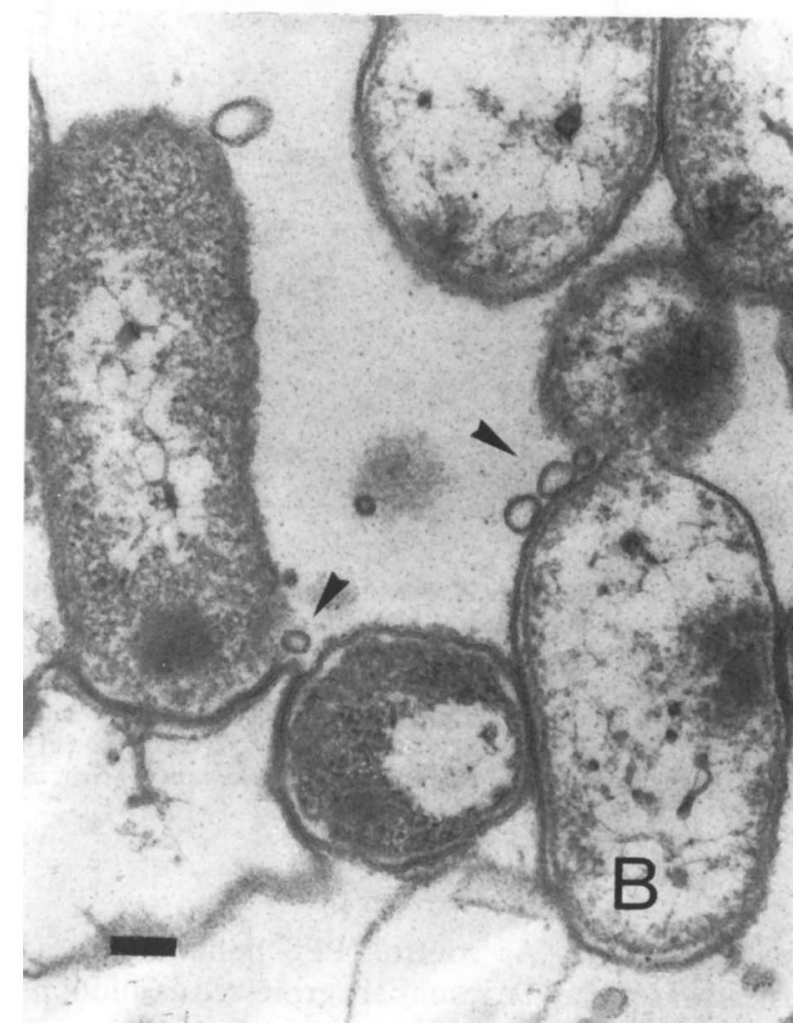

Fig. 2. Electronmicroscopy of a thin section of $H$. ducreyi strain CCUG 7470. a, The typical cell wall of gram-negative bacteria, cell-membrane and outer membrane clearly visible; $\mathbf{b}$, formation of blebs (arrows). Bar, $0 \cdot 1 \mu \mathrm{m}$.

Fig. 3. Electronmicroscopy studies of $\boldsymbol{H}$. ducreyi bacteria cultivated on solid or in liquid media. a and b, Strain CCUG 7470 (solid medium) stained with rabbit anti-24-kDa serum and with gold goat-anti-rabbit IgG; c, strain CCUG 7470 (liquid medium) stained with rabbit anti24-kDa serum and gold goat-anti-rabbit IgG; d, strain CCUG 4438 (solid medium) stained with rabbit anti-24-kDa serum and gold goat-antirabbit IgG; e, strain CCUG 7470 (liquid medium) stained with pre-immune serum (control) and gold goat-anti-rabbit IgG; f, strain CCUG 7470 (solid medium) stained with rabbit anti-24-kDa serum without gold-labelling. Bars, $0 \cdot 2 \mu \mathrm{m}(\mathbf{a}, \mathbf{d}, \mathbf{e}), 0 \cdot 05 \mu \mathrm{m}(\mathbf{b}), 0 \cdot 02 \mu \mathrm{m}(\mathbf{c}), 0 \cdot 1 \mu \mathrm{m}(\mathbf{f})$. 

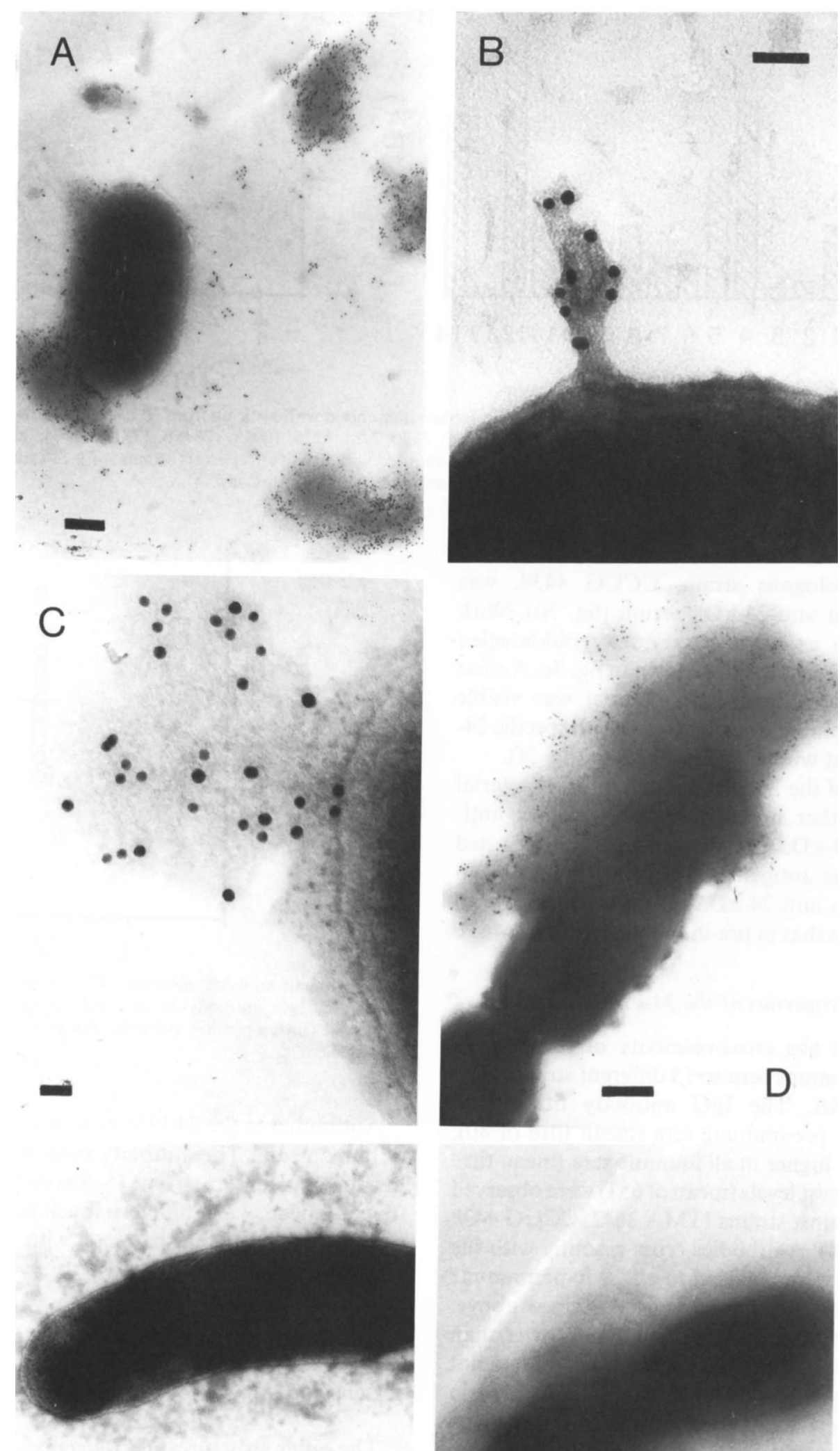

E

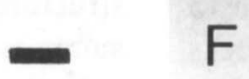




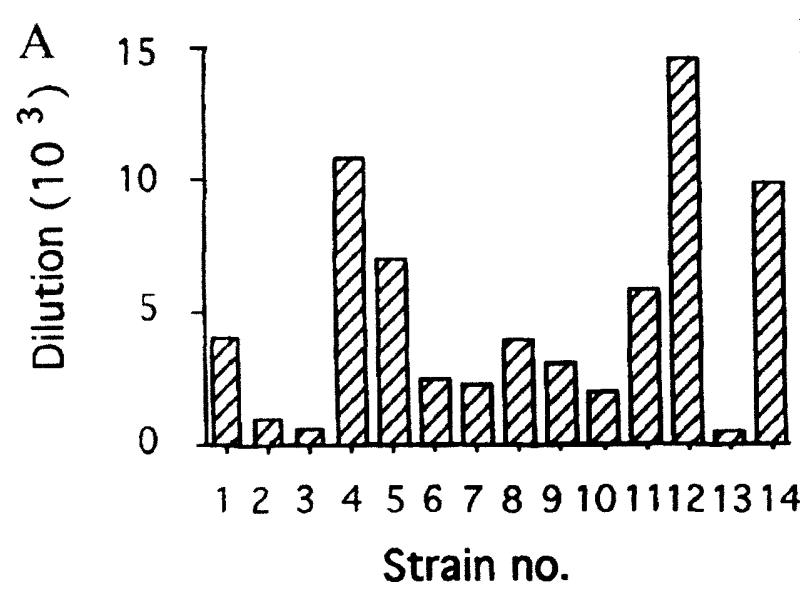

B

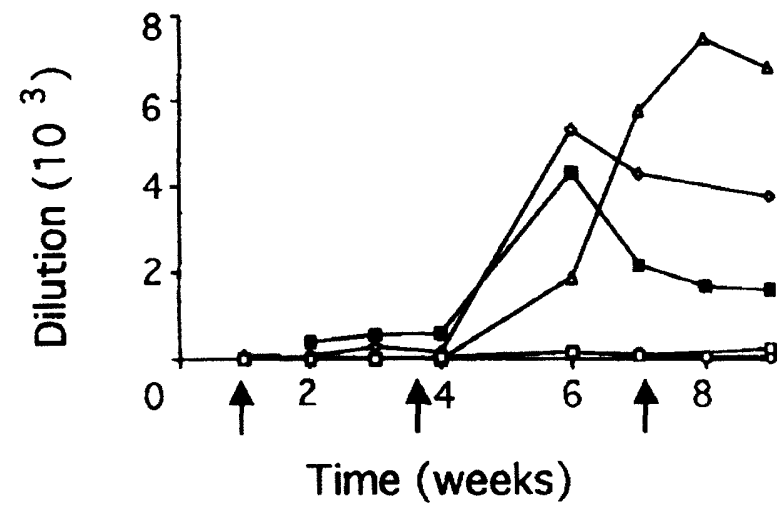

Fig. 4. A. Serum levels of $\mathrm{IgG}$ antibody to the 24-kDa protein in rabbits immunised with sonicate from $H$. ducreyi strains; nos. 1-14: ITMA 3207, 3542, CCUG 4438, 7470 (immunised with the 24-kDa protein), 7470, 7781, 9276, 10045, 17675B, 17713, 18804, 26693, $27011,27014$. B. Serum $\operatorname{lgG}$ antibody response to the $24-\mathrm{kDa}$ protein in rabbits immunised with five live $H$. ducreyi strains : $-\square-$, strain $3542 ;-\diamond-$, strain $3207 ;-\bigcirc^{-}$, strain $4438 ;-\Delta^{-}$, strain $7470 ;-\square-$, strain 10045. Arrows indicate timing of doses.

shown in figs. $3 \mathrm{~b}$ and $\mathrm{c}$. A similar structure was noted when the heterologous strain, CCUG 4438, was treated with gold anti-24-kDa serum (fig. 3d). With pre-immune sera as control, very few gold-labelled antibodies were detectable, as shown in fig. 3e. A clear outer high-density filamentous material was visible when negative staining was performed with specific 24$\mathrm{kDa}$ antisera, but without gold labelling (fig. $3 \mathrm{f}$ ).

Localisation of the 24-kDa protein on the bacterial surface was further investigated with specific antiserum to the $24-\mathrm{kDa}$ protein band and evaporated whole bacteria as antigen in ELISA. The IgG mean antibody titre in anti-24-kDa serum was $4860, c .10$ times higher than that in pre-immune serum ( 1 in 463 ).

\section{Immunological properties of the 24- $k$ Da protein}

To investigate the cross-reactivity of the $24-\mathrm{kDa}$ protein, hyperimmune sera to 13 different strains were tested by ELISA. The IgG antibody titres were generally low in pre-immune sera (mean titre of 80 ), but significantly higher in all immune sera (mean titre of 4780). The lowest levels (mean of 651) were observed in three sera, against strains ITMA 3542, CCUG 4438 and 27011 (fig. 4). Antibodies cross-reacting with the 24-kDa protein were detected in all 19 hyperimmune sera to the gram-negative bacteria described above. However, the levels were about six times lower than those to $H$. ducreyi, the mean titre being 536 (data not shown). The cross-reactivity of the $24-\mathrm{kDa}$ protein among $H$. ducreyi strains was further confirmed by Western blotting with antisera to seven $\boldsymbol{H}$. ducreyi strains (data not shown).

The IgG antibody responses in rabbits to two intradermal injections with five live $H$. ducreyi strains (CCUG 4438, 7470, 10045, ITMA 3207 and 3542) were monitored by ELISA. There was a significant, mainly secondary, increase, in antibody response to strains CCUG 7470, 10045 and ITMA 3207 whereas the antibody response to strains CCUG 4438 and ITMA 3542 was low (fig. 4b).

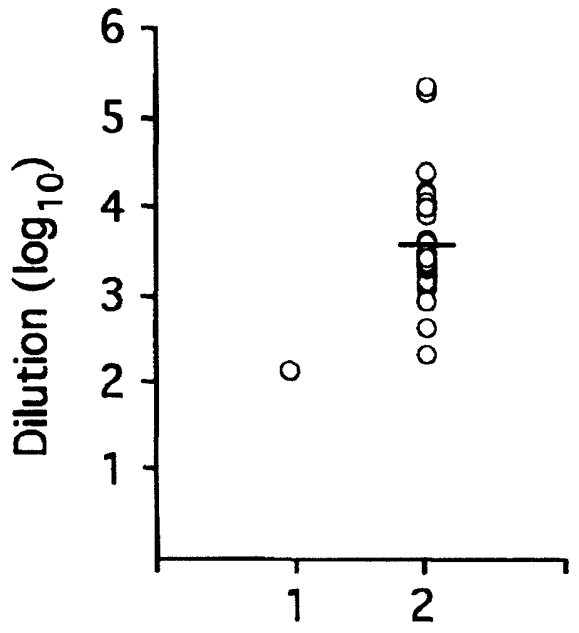

Fig. 5. Human antibody response: 1 , pool of sera from 15 blood donors. 2, IgG antibody to the $24-\mathrm{kDa}$ protein in sera from chancroid culture-positive patients; the geometric mean value is indicated.

Antibodies to the 24-kDa protein were also detected in human sera. The antibody titres were consistently low in pooled sera from 15 Swedish blood donors (overall mean, 129), but very much higher in 26 of 28 serum samples from patients with culture-verified chancroid, ranging from 796 to $2 \times 10^{5}$ (geometric mean, 3682) (fig. 5).

\section{Discussion}

The outer structures of $H$. ducreyi and their role in the pathogenesis of chancroid has not been fully investigated. Many pathogenic bacteria have different surface appendages that enable them to adhere, colonise and ultimately give rise to infection. It has been reported that $H$. ducreyi has fimbria-like structures, consisting of $24-\mathrm{kDa}$ monomeric protein subunits. ${ }^{13}$

In this study, the 24-kDa protein was purified and a polymeric form of $c .165 \mathrm{kDa}$ was demonstrated. 
Moreover, localisation of the $24-\mathrm{kDa}$ protein was assessed by immuno-electronmicroscopy and confirmed by ELISA.

The polymeric form of the $24-\mathrm{kDa}$ protein was observed by SDS-PAGE of a non-heated sample, and the correlation between the $24-$ and $165-\mathrm{kDa}$ form of the protein was verified by immunoblotting of the crude protein solution. Adding or omitting 2mercaptoethanol in the sample buffer during purification of the $24-\mathrm{kDa}$ protein did not affect the aggregative properties of the protein, as outlined above. This suggests that monomers of the $24-\mathrm{kDa}$ protein have the capacity to aggregate and form a higher molecular mass polymer of $c .165 \mathrm{kDa}$. Possibly this $165-\mathrm{kDa}$ polymer represents a fibrillate structure or filamentous material with subunits of $24 \mathrm{kDa}$, although it was difficult to visualise clearly the fibrillate structure by electronmicroscopy by the negative staining procedure described.

The N-terminal amino-acid sequence of the $24-\mathrm{kDa}$ protein revealed no homology with the amino-acid sequence of pili from $H$. influenzae, E. coli type 1 or $\mathrm{P}$ or $N$. gonorrhoeae, as reported by Guerina and coworkers. ${ }^{24}$ In the present study, the 25 amino-acid sequence included all but three (cysteine, glutamic acid and tyrosine) of the amino-acid composition previously reported for the $24-\mathrm{kDa}$ protein. ${ }^{13}$ However, one amino acid not previously described was also detected (glutamine). The different methods used for the identification of some amino acids when assessing the composition and sequence might explain these discrepancies. The sequence described here has not been reported previously.

Thin sections of strain 7470 revealed a cell wall typical of gram-negative bacteria, and close cellular contact which probably contributes to the characteristic clumping observed with $H$. ducreyi. The presence of blebs is suggestive of outer membrane shedding into the surroundings, similar to that seen with other gram-negative bacteria. ${ }^{18}$

These results suggest the presence of a filamentous structure comprising the $24-\mathrm{kDa}$ protein at the cell surface. The existence of this structure confirms previous findings of extracellular material observed with negative staining by electronmicroscopy, reported both by $\mathrm{us}^{23}$ and by others. ${ }^{12}$ Whether cultivated on solid or in liquid media, the three strains examined revealed highly dense material, both cell-associated and as free aggregates with gold incorporated. When staining with anti-24-kDa sera, without gold-labelling, an unbroken high density covering layer was observed. However, the addition of the second gold-labelled antibody may have contributed to the fragmentary morphology observed, especially when compared with the use of anti-24-kDa antibodies only. A similar

\section{References}

1. Morse SA. Chancroid and Haemophilus ducreyi. Clin Microbiol Rev 1989; 2: 137-157.

2. Willis SE. Chancroid. Prim Care 1990; 17: 145-152. appearance of released aggregates has been observed when performing immunolabelling with surfacelocated high mol. wt proteins of non-typable $H$. influenzae. ${ }^{25}$ In addition, shedding of FHA from $B$. pertussis has also been reported to occur when live cells are applied to grids, ${ }^{26}$ and prefixing has been reported to give FHA a fragmentary aggregated appearance. ${ }^{27}$ Negative staining with pre-immune serum showed a low degree of gold incorporation, possibly originating from low levels of pre-immune antibodies. ${ }^{7}$

The binding of anti-24-kDa antibodies to whole bacteria used in ELISA supports the evidence that the 24-kDa protein is located at the surface of the bacteria. The antibodies detected with ELISA of pre-immune serum possibly reflect the presence of antibodies to other structures on the bacteria, as described previously. ${ }^{7}$ However, it must be borne in mind that some degree of distortion of the dried bacteria is possible and that this may provide access to other antigens.

Anti- $H$. ducreyi rabbit sera have been reported to cross-react with other species of Haemophilus, as well as with Pasteurella and Actinobacillus spp. ${ }^{15}$ probably as a result of sharing of common antigens. It has also been shown by Western blotting that a number of antigens are detected with rabbit pre-immune sera and with sera obtained after immunisation with $H$. ducreyi. ${ }^{16}$

In this study, within-species cross-reactivity and cross-reactivity with other gram-negative bacterial species was shown to be dependent, at least to some degree, on the 24-kDa antigen. The three strains of $H$. ducreyi (ITMA 3542, CCUG 4438 and 27011) resulting in the lowest antibody response and the lowest levels of antibodies in hyperimmune sera to bacterial sonicates have also been reported to be unable to produce detectable levels of cytotoxin. ${ }^{8}$

We have also shown that 26 of 28 sera from cultureverified chancroid patients had high titres of antibody to the 24-kDa protein, thus confirming its immunogenicity in human disease. Although the function of the 24-kDa protein has not yet been determined, the outer structure may contribute to bacterial adherence or be involved in the protection of the bacteria, or both.

In conclusion, $H$. ducreyi is surrounded by a high density filamentous material comprising the $24-\mathrm{kDa}$ protein. This protein may represent subunits constituting a fimbrillate protein structure of high mol. wt. This is immunogenic in experimental animals, cross-reactive within species and to some extent with other gram-negative bacteria, and is probably relevant as an antigen in human disease.

This work was supported by grants from the Swedish Agency for Research Cooperation with Developing Countries (SAREC). 
immunodeficiency virus from genital ulcers in Nairobi prostitutes. J Infect Dis 1989; 160: 380-384.

5. Kreiss JK, Koech D, Plummer FA et al. AIDS virus infection in Nairobi prostitutes. Spread of the epidemic to East Africa. $N$ Engl J Med 1986; 314: 414418.

6. Nsanze H, Fast MV, D'Costa LJ, Tukei P, Curran J, Ronald AR. Genital ulcers in Kenya. Clinical and laboratory study. Br J Vener Dis 1981 ; 57: 378-381.

7. Lagergård $\mathrm{T}$. The role of Haemophilus ducreyi bacteria, cytotoxin, endotoxin and antibodies in animal models for study of chancroid. Microb Pathog 1992; 13: 203-217.

8. Purvén M, Lagergård T. Haemophilus ducreyi, a cytotoxinproducing bacterium. Infect Immun 1992; 60: 1156-1162.

9. Odumeru JA, Wiseman GM, Ronald AR. Relationship between lipopolysaccharide composition and virulence of Haemophilus ducreyi. J Med Microbiol 1987; 23: 155-162.

10. Odumeru JA, Wiseman GM, Ronald AR. Role of lipopolysaccharide and complement in susceptibility of Haemophilus ducreyi to human serum. Infect Immun 1985; 50: $495-499$.

11. Jann K, Hoschützky H. Nature and organization of adhesins. Curr Top Microb Immunol 1990; 151: 55-70.

12. Albritton WL. Biology of Haemophilus ducreyi. Microb Rev 1989: 53: 377-389.

13. Spinola SM, Castellazzo A, Shero M, Apicella MA. Characterization of pili by Haemophilus ducreyi. Microb Pathog 1990; 9: 417-426.

14. Johnson AP, Abeck D, Davis HA. The structure, pathogenicity and genetics of Haemophilus ducreyi. J Infect 1988; 17: 99-106.

15. Slootmans L, Vanden Berghe DA, Piot P. Typing Haemophilus ducreyi by indirect immunofluorescence assay. Genitourin Med 1985; 61: 123-126.

16. Saunders JM, Folds JD. Immunoblot analysis of antigens associated with Haemophilus ducreyi using serum from immunised rabbits. Genitourin Med 1986; 62 : 321-328.

17. Laemmli UK. Cleavage of structural proteins during the assembly of the head of bacteriophage T4. Nature 1970 227: 680-685.
18. Mattsby-Baltzer I, Lindgren K, Lindholm B, Edebo L. Endotoxin shedding by enterobacteria: free and cell-bound endotoxin differ in Limulus activity. Infect Immun 1991; 59: 689-695.

19. Bradford MM. A rapid and sensitive method for the quantitation of microgram quantities of protein utilizing the principle of protein-dye binding. Anal Biochem 1976; 72: 248-254.

20. Lagergård $T$, Purvén $M$. Neutralizing antibodies to Haemophilus ducreyi cytotoxin. Infect Immun 1993; 61: 1589-1592.

21. Dahlberg T, Branefors P. Enzyme-linked immunosorbent assay for titration of Haemophilus influenzae capsular and $\mathrm{O}$ antigen antibodies. $J$ Clin Microbiol 1980; 12: 185-192.

22. Towbin H, Staehelin T, Gordon J. Electrophoretic transfer of proteins from polyacrylamide gels to nitrocellulose sheets: procedure and some applications. Proc Natl Acad Sci USA $1979 ; 76: 4350-4354$.

23. Lagergård T, Purvén M, Frisk A. Evidence of Haemophilus ducreyi adherence to and cytotoxin destruction of human epithelial cells. Microb Pathog 1993; 14: 417-431.

24. Guerina NG, Langermann S, Schoolnik GK, Kessler TW, Goldmann DA. Purification and characterization of Haemophilus influenzae pili, and their structural and serological relatedness to Escherichia coli $\mathbf{P}$ and mannosesensitive pili. J Exp Med 1985; 161 : 145-159.

25. Bakaletz LO, Barenkamp SJ. Localization of high-molecularweight adhesion proteins of nontypable Haemophilus influenzae by immunoelectron microscopy. Infect Immun $1994 ; 62$ : $4460-4468$.

26. Watanabe H, Kanesaki S, Shukuda Y, Mayahara H. The location of filamentous hemagglutinin and pertussis toxin antigens of Bordetella pertussis by immunoelectron microscopy. J Electron Microsc 1989; 38: 172-181.

27. Ashworth LAE, Dowsett AB, Irons LI, Robinson A. The location of surface antigens of Bordetella pertussis by immuno-electron microscopy. Dev Biol Standard 1985; 61: $143-151$. 